\title{
An Overview on the Effect of Neonicotinoid Insecticides on Mammalian Cholinergic Functions through the Activation of Neuronal Nicotinic Acetylcholine Receptors
}

\author{
Jean-Noël Houchat, Alison Cartereau, Anaïs Le Mauff, Emiliane Taillebois and \\ Steeve H. Thany *(D) \\ University of Orleans, LBLGC USC INRAE 1328. 1 rue de Chartres, 45060 Orléans, France; \\ jean-noel.houchat@univ-orleans.fr (J.-N.H.); alison.cartereau@univ-orleans.fr (A.C.); \\ anais.le-mauff@univ-orleans.fr (A.L.M.); emiliane.taillebois@univ-orleans.fr (E.T.) \\ * Correspondence: steeve.thany@univ-orleans.fr
}

Received: 1 April 2020; Accepted: 30 April 2020; Published: 6 May 2020

check for updates

\begin{abstract}
Neonicotinoid insecticides are used worldwide and have been demonstrated as toxic to beneficial insects such as honeybees. Their effectiveness is predominantly attributed to their high affinity for insect neuronal nicotinic acetylcholine receptors (nAChRs). Mammalian neuronal $n A C h R s$ are of major importance because cholinergic synaptic transmission plays a key role in rapid neurotransmission, learning and memory processes, and neurodegenerative diseases. Because of the low agonist effects of neonicotinoid insecticides on mammalian neuronal $\mathrm{nAChRs,} \mathrm{it} \mathrm{has} \mathrm{been}$ suggested that they are relatively safe for mammals, including humans. However, several lines of evidence have demonstrated that neonicotinoid insecticides can modulate cholinergic functions through neuronal nAChRs. Major studies on the influence of neonicotinoid insecticides on cholinergic functions have been conducted using nicotine low-affinity homomeric $\alpha 7$ and high-affinity heteromeric $\alpha 4 \beta 2$ receptors, as they are the most abundant in the nervous system. It has been found that the neonicotinoids thiamethoxam and clothianidin can activate the release of dopamine in rat striatum. In some contexts, such as neurodegenerative diseases, they can disturb the neuronal distribution or induce oxidative stress, leading to neurotoxicity. This review highlights recent studies on the mode of action of neonicotinoid insecticides on mammalian neuronal $\mathrm{nAChRs}$ and cholinergic functions.
\end{abstract}

Keywords: ACh; cholinergic functions; nicotinic receptors; modulation; neonicotinoid insecticides

\section{Introduction}

Neonicotinoid insecticides have contributed to improvements in global agricultural productivity for decades by controlling insects and plant pathogens, providing higher crop yields and improved product quality. Over the last ten years, the extensive use of neonicotinoid insecticides has been criticized due to the risks associated with their toxicity to humans and other non-target species. Neonicotinoid insecticides include several compounds, such as imidacloprid (IMI), acetamiprid (ACE), clothianidin (CLT), and thiamethoxam (TMX), which act on neuronal nicotinic acetylcholine receptors (nAChRs). They are considered as partial or full agonists of insect neuronal nAChRs and poor agonists of mammalian receptors. Full agonists are compounds that, at saturation concentrations, activate the channels to a near $100 \%$ open probability. Thus, ACh is a full agonist of nAChRs. Consequently, partial agonists will evoke less total current than full agonists and occupy the same binding site. They can also inhibit receptor activation by endogenous or exogenous full agonists. Thus, the same compound can be a full agonist of one subtype of nAChRs, and a partial agonist or antagonist of another subtype. 
Moreover, $\mathrm{nAChRs}$ are considered as prototypical allosteric proteins that undergo conformational changes upon the binding of a ligand [1-3]. Agonists bind to the ligand-binding or orthosteric site on the ligand-binding domain. Allosteric modulators are pharmacological compounds that bind to the receptor at a distinct site from the ligand-binding domain and change the free energy associated with transitions between functional states. This leads to the activation (positive allosteric modulators) or reduction of the ligand-evoked response (negative allosteric modulators) (Figure 1). The cholinergic system in mammals has been studied extensively. It is known that it provides diffuse innervation to the entire brain, driving and modulating a wide variety of behaviors. ACh is released from presynaptic cholinergic axon terminals and binds to the extracellular ligand-binding domain of the nAChRs. Thus, through neuronal nAChRs, ACh regulates processes such as cell excitability and neuronal integration. These processes influence physiological functions, leading to the involvement of neuronal nAChRs in many diseases such as Alzheimer's and Parkinson's disease [4-7]. Given the role of neuronal nAChRs in both insects and mammals, few studies have described the involvement of neonicotinoid insecticides on mammalian cholinergic functions through neuronal nAChRs. Therefore, in this work, we aim to provide an overview of recent studies on the involvement of neonicotinoid insecticides on neuronal cholinergic functions.

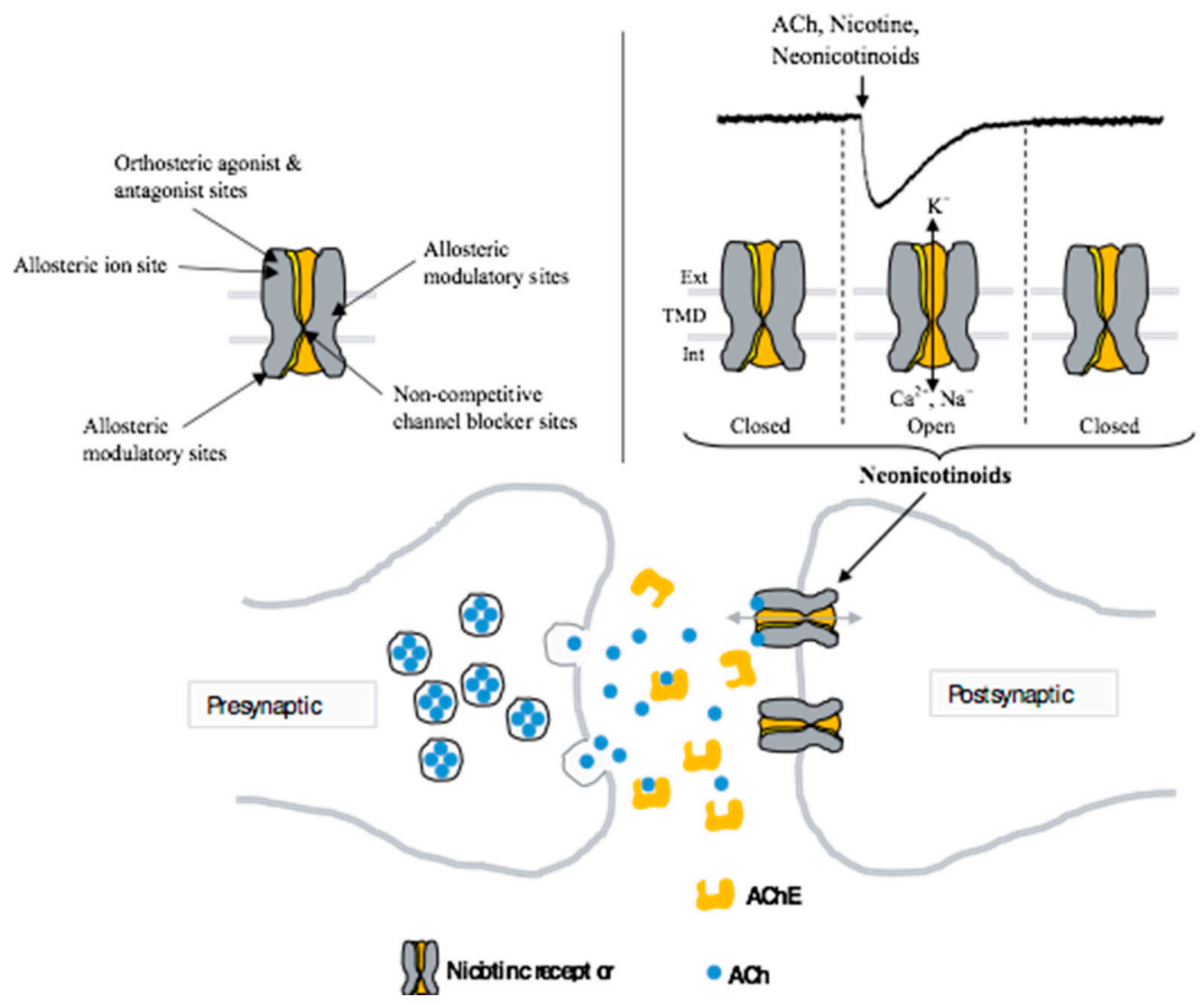

Figure 1. Representation of the cholinergic synapse and ion channel selectivity. The neuronal nicotinic acetylcholine receptors (nAChRs) are located at the postsynaptic terminal. Agonist, antagonist, noncompetitive channel blocker, and allosteric sites are represented in the cut-away view showing four of the five subunits forming the pentameric receptor-channel complex. Ext: Extracellular; TMD: transmembrane domain; Int: intracellular. 


\section{Diversity of Mammalian Neuronal Nicotinic Acetylcholine Receptors}

\subsection{Multiple Receptor Subtypes and Different Pharmacological Properties}

Mammalian neuronal $\mathrm{nAChRs}$ are of significant importance because cholinergic synaptic transmission plays a key role in rapid neurotransmission, learning, and memory processes. Neuronal nAChRs are composed of 17 homologous genes coding for $\mathrm{nAChR}$ subunits [8,9]. These subunits can be divided into two subgroups: the muscle-type receptor composed of a heteromeric receptor $(\alpha 1 \beta \gamma(\varepsilon) \delta)$, and the neuronal-type receptor, which is more complex in terms of the number of subunits and combinations. They incorporate different subunits and are composed of: (1) Homomeric receptors which are comprised of one subunit, $\alpha 7, \alpha 8, \alpha 9$, or $\alpha 10$, which can form an $\alpha 9 \alpha 10$ heteromeric receptor; (2) heteromeric receptors, which are formed by subunits $\alpha 2-\alpha 6$ in combination with $\beta 2-\beta 4$. Consequently, multiple receptor subtypes can be formed with different stoichiometry, subunit combinations, and pharmacological properties [10]. Thus, when opened, neuronal nAChRs are cation-selective channels that permit the flow of sodium $\left(\mathrm{Na}^{+}\right)$, potassium $\left(\mathrm{K}^{+}\right)$, and calcium $\left(\mathrm{Ca}^{2+}\right)$ ions across the membrane (Figure 1). A net influx of cations through the channel pore depolarizes the cell membrane and increases neuronal excitability. The impact of neuronal nAChR activation on cholinergic function depends on subunit composition because each nAChR subtype has unique activation, agonist selectivity, channel conductance, and desensitization properties. The vast majority of subunit combinations have not been studied, and a significant number of publications on neonicotinoid modes of action refer to the low-affinity homomeric $\alpha 7$ and high-affinity heteromeric $\alpha 4 \beta 2$ receptors because they are the most abundant in the nervous system [11]. For heteromeric receptors such as $\alpha 4 \beta 2$, the ratio of subunits forming the receptors may have an influence on the pharmacological properties of the receptors [12-17]. For example, receptors with the composition $(\alpha 4 \beta 2)_{2} \alpha 4$ exhibit higher single-channel conductance and a shorter mean open lifetime than receptors with the composition $(\alpha 4 \beta 2)_{2} \beta 2$ [16]. Moreover, long-term exposure of $\alpha 4 \beta 2$ receptors to nicotine causes an increase in the number of binding sites at the cell surface, known as up-regulation, whereas $\alpha 7$ desensitizes rapidly in response to high agonist concentrations [18] and has a high relative permeability to calcium $[19,20]$. Indeed, it is known that nicotine has a low affinity for $\alpha 7$ receptors, and high doses of nicotine may be required for the regulation of the $\alpha 7$ receptor. The different modulatory effect of nicotine on both $\alpha 7$ and $\alpha 4 \beta 2 \mathrm{nAChRs}$ suggests that different mechanisms may activate the up-regulation of $\alpha 7$ and $\alpha 4 \beta 2$.

\subsection{Neonicotinoids Are Poor Activators of Mammalian Neuronal nAChRs}

The discovery of neonicotinoid insecticides from a lead compound, leading to nithiazine, then followed by the synthesis of IMI, has been described in various degrees [21-23]. Nicotine and neonicotinoids have some structural similarities (especially IMI), and act on the same receptor subtype but in a different way. Interactions between neuronal $\mathrm{nAChRs}$ and neonicotinoids are studied by measuring inward currents caused by neonicotinoids. It has been recognized that neonicotinoids activate insect neuronal nAChRs as agonists in different ways [24]. As one of the most widely used neonicotinoid insecticides in the world, IMI is known as a partial agonist, while CLT and ACE are "super" agonists. In contrast, TMX is a poor agonist, despite being able to activate synaptic activity [25]. Unfortunately, there are few studies relating to the mode of action of neonicotinoid insecticides on mammalian neuronal nAChRs. Using clonal rat pheochromocytoma (PC12) cells, Nagata et al. demonstrated that IMI weakly activated nAChRs with conductance states identical to those of ACh-generated currents [26]. Moreover, using a single-channel patch-clamp method, they found that co-application of both IMI and ACh resulted in a decrease in the mean open time and mean burst duration of the currents of main conductance states, compared with those induced by $\mathrm{ACh}$ alone [26]. Ihara et al. found that IMI, nitenpyram (NTP), and CH-IMI (the nitromethylene analog of IMI), all induced inward currents which were rapidly desensitized. However, IMI and NTP were partial agonists on the $\alpha 7$, whereas CH-IMI and DN-IMI (the desnitro derivative of IMI) were full agonists because their currents were closed to that of the ACh [27]. Similarly, on the $\alpha 4 \beta 2$ receptors, 
it was found that IMI, CH-IMI, and NTP were inactive as agonists, whereas DN-IMI—which lacks the nitro group - was a full agonist [27]. The weak action of neonicotinoids on the $\alpha 4 \beta 2$ receptor was attributed in part to the $\beta 2$ subunit lacking basic residues in loop $\mathrm{D}$. This led to the idea that "insect-selective" residues confer neonicotinoid sensitivity by direct interactions or changes in the $\alpha$ subunit conformations [27]. Overall, this poor agonist action of neonicotinoids on $\alpha 7$ and $\alpha 4 \beta 2$ nAChRs explains the lack of substantial data concerning the effect of these compounds on other mammalian nAChRs, considering their diversity within the mammalian nervous system.

\section{Detoxification Mechanisms in Mammals in Regards to Neonicotinoid Sensitivity}

The higher sensitivity of insects to neonicotinoid insecticides relative to mammals may be due to several factors. Firstly, it may relate to enzymatic detoxification mechanisms, which are important considering that the metabolite will not affect the receptor target. In this case, it has been considered that changes in xenobiotic-metabolic enzyme expression, and particularly the overexpression of cytochrome P450, are associated with increased neonicotinoid resistance in insects [28-34]. Thus, the toxicity of neonicotinoids in insects could be explained as a lack of, or decrease in, the physiological activity of detoxifying enzymes [35,36]. This difference was found between the bees Apis mellifera and Apis cerana, in which it was demonstrated that A. cerana was more sensitive to IMI and CLT compared to $A$. mellifera, in part because glutathione-S-transferase activity was significantly higher in A. mellifera [36]. Unfortunately, no study refers to the effectiveness of these enzymatic mechanisms in mammals with regards to neonicotinoid resistance or sensitivity. Considerable efforts have been made to identify neonicotinoid insecticide metabolism in mammals [37-43]. Human CYP450 enzymes, and in particular, CYP3A4, 2C19, and 2B6, have been found to convert TMX to CLT. CYP3A4, 2C19, and 2A6 metabolized CLT to desmethy l-CLT, and CYP2C19 converted TMX to desmethyl-TMX [42]. These enzymes were involved with considerable amounts of neonicotinoid substrates, which increased or decreased in different parts of the mammalian body, such as the liver and brain. In other studies, it was considered that because of this enzymatic activity, neonicotinoids such as TMX could be hepatotoxic and hepatocarcinogenic [44-46]. Consequently, the complex activity of detoxifying enzymes in mammals is no longer associated with their ability to provide resistance to neonicotinoids, but with their capacity to increase toxicity. It was also proposed that insecticides are more effective at the ambient temperature of insects (around $15-20^{\circ} \mathrm{C}$ ) than that of mammals (if we consider $36{ }^{\circ} \mathrm{C}$ as a reference temperature). However, this hypothesis seems to have been challenged by findings that neonicotinoids show significantly lower efficacy at low temperatures (between 14 and $22^{\circ} \mathrm{C}$ ) when used to manage the Drosophila suzukii (Matsumura) [47]. Acute toxic assays on aquatic insects such as the mayfly Isonychia bicolor demonstrated an increase in IMI uptake with increasing environmental temperatures [48]. According to these studies, it appears that an increase in environmental temperature was more effective as a factor inducing physiological variations, leading to neonicotinoid toxicity in the insects. Indeed, Mao et al. proposed that the sensitivity of Nilaparvata lugens to NTP and other insecticides increased significantly when the temperature changed from 18 to $36^{\circ} \mathrm{C}$. They also found that this increase in sensitivity was correlated to a decrease in cytochrome $\mathrm{P} 450$ activity [49]. Their latter observation appears more comprehensive considering that a great proportion of mammals, including humans, have a temperature around $36^{\circ} \mathrm{C}$, and that a decrease in detoxifying enzyme activities will result in the activation of the neonicotinoid targets. Thirdly, if we agree that most neonicotinoids undergo metabolic modifications at multiple sites in both insects and mammals, we must presume that the mechanisms by which neonicotinoids could be toxic to mammals are predominantly associated with their neuronal targets, the nAChR subtypes. Thus, two hypotheses can be made: (i) neonicotinoids will directly activate neuronal nAChRs as agonists, leading to excitation of the cholinergic system; (ii) neonicotinoids are not able to activate (or poorly activate) mammalian neuronal nAChRs at a binding site and will be considered as modulators. Thus, much of the remaining knowledge concerning the toxic effect of neonicotinoids should be considered in regard to their modulatory activity on mammalian cholinergic function and neuronal nAChRs. 


\section{Alterations of Cholinergic Functions}

\subsection{Modulation of Mammalian Neuronal nAChR Function}

The major problem found with neonicotinoid insecticides is to always consider them as agonists of neuronal nAChRs (Figure 2). Indeed, despite neonicotinoids being poor activators of neuronal nAChRs, several studies have demonstrated that they can interact with $\mathrm{nAChR}$ agonists [50-52]. In a previous study, Matsuda et al. found that the responses of $\alpha 4 \beta 2$ to ACh were potentiated by IMI [53]. Toshima et al. proposed that ACh-evoked currents through chicken $\alpha 4 \beta 2$ receptors can be potentiated by CLT and IMI [52]. To address the mechanism of potentiation, they studied the effect that co-application of IMI and CLT had on the concentration-response curve of ACh. In the presence of IMI and CLT, the ACh concentration-response curve for $\alpha 4 \beta 2$ was shifted to the left, whereas thiacloprid (THC) shifted the curve to the right, and was also able to inhibit ACh-evoked currents [52]. These results demonstrated that IMI, CLT, and THC have differential action on mammalian neuronal nAChRs, which may be due to their activity on a particular site in the nAChRs [54]. Thus, we propose that the first effect of neonicotinoids on mammalian neuronal $\mathrm{nAChRs}$ is to disrupt $\mathrm{nAChR}$ responses to the endogenous ligand, ACh. Exposure of HEK cells expressing human $\alpha 4 \beta 2$ receptors to CLT and IMI showed inward currents of low amplitudes. However, IMI strongly reduced ACh responses, whereas CLT enhanced the responses. This difference was associated with the subunit stoichiometry of $\alpha 4 \beta 2$ receptors containing three $\alpha$ subunits rather than two $\alpha$ subunits (as with IMI), and CLT inhibited ACh-evoked currents [50]. One of the major questions has been to demonstrate whether a similar effect would be seen with a homomeric receptor where the fifth position is occupied by the same subunit. Recently, using $\alpha 7$ homomeric nAChRs, we demonstrated that the co-application of low concentrations of CLT and acetamiprid (ACE) with ACh did not change ACh-evoked current amplitudes. However, pretreatment before the application of ACh significantly increased ACh-evoked currents by almost two-fold [51]. To confirm the modulatory effect of neonicotinoids, we used TMX, which is known as ineffective against mammalian neuronal nAChRs. A low concentration of TMX decreased the ACh-induced currents through the $\alpha 7$ receptor when it was co-applied or pretreated [51]. All these results reinforce the idea that the mode of action of neonicotinoid insecticides is more attributable to their modulatory effect on mammalian receptors than agonist efficacy. Indeed, through the modulatory effect we are able to understand why they can disturb cholinergic synaptic transmission.

\subsection{Are Neonicotinoid Insecticides Able to Interact with Mechanisms Involved in Neurodegenerative Diseases?}

The involvement of pesticides in neurodegenerative diseases has been the subject of several polemics, particularly over the past 10 years. This is due to the extensive use of pesticides in the environment and growing evidence demonstrating that they can disturb the development of the mammalian central nervous system [55-57]. Controversies have also been fueled by the fact that epidemiological evidence is far from conclusive, as considerable heterogeneity has been observed between the patients and chemicals involved. In addition, neurodegenerative diseases are complex syndromes resulting from different genetic and environmental factors that give rise to various degrees of cognitive deficits, motor deficits, and other functions. Nevertheless, oxidative stress and apoptosis have been well investigated as neurotoxic mechanisms leading to the toxic effect of several pesticides [58-60]. However, few studies have indicated that neonicotinoid exposure could be associated with neurodegenerative disease. Recently, Dhouib et al. suggested that curcumin, which has anti-inflammatory, antioxidant, and anti-tumor properties, protects rats against ACE-induced cerebellum toxicity, such as an increase in AChE activities, a decline in cell viability, and oxidative stress [61]. Moreover, Kagawa and Nagao found that mice embryos exposed to ACE from day 6 to day 13 developed hypoplasia of the cortical plate and decreased neurogenesis. Newborn ACE-exposed mice showed an abnormal neuronal distribution in the neocortex, increased numbers of the microglial marker Iba1, and the active microglia had a globular structure (amoeboid-type microglia) [57]. In some contexts, in pathological states such as Parkinson's disease, it has been proposed that inappropriate 
microglial activation contributes to neurodegeneration through the production of cellular oxidants and cytokines [62,63]. The current treatment for Alzheimer's disease (AD) is acetylcholinesterase (AChE) inhibitors, which partially block the degradation of ACh in the synapse and enable more of the neurotransmitter to reach and activate cholinergic receptors [64]. It was also found that nAChR density decreased with disease progression, suggesting a link between beta-amyloid $(A \beta)$ and nAChR function [65]. Soluble $A \beta$ species, particularly oligomeric $A \beta 1-42$, interacts with several $n A C h R$ subtypes [66]. In addition, $\mathrm{AD}$ is also associated with the deterioration of memory and cognitive function. With a base chemical structure similar to nicotine, and because neuronal nAChRs are considered to be affected in several neurodegenerative diseases $[65,66]$, additional studies are needed to further explore the potential involvement of neonicotinoid insecticides on neurodegenerative diseases through neuronal nAChRs.

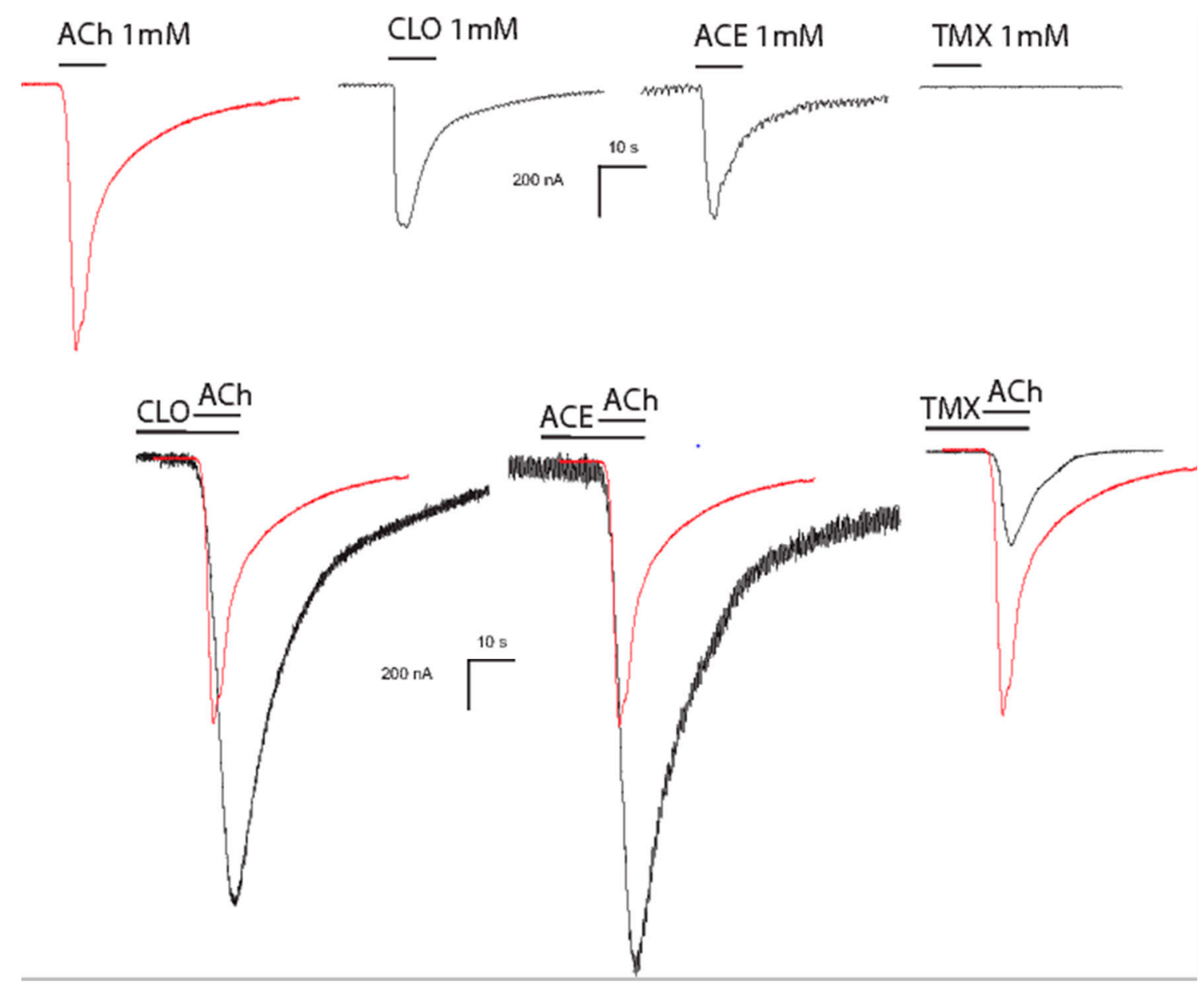

Figure 2. Effects of neonicotinoids on ACh-evoked current amplitudes. Clothianidin (CLT) and acetamiprid (ACE) enhance ACh-induced current amplitudes of the mammalian $\alpha 7$ neuronal nAChRs and thiamethoxam (TMX) decreases ACh-induced current amplitudes.

\subsection{Neonicotinoid Insecticides Affect Other Mammalian Neuronal Mechanisms}

Mammalian neuronal nAChRs are involved in several functions, such as the release of dopamine in the striatal region, glutamatergic synapse formation, and brain development [67-69]. The effect of IMI on the properties of stellate cells of the ventral cochlear nucleus (VCN) demonstrated that it increased neuronal excitability and caused a depolarizing shift in the membrane potential. The IMI effect was blocked by the specific nicotinic receptor antagonists d-tubocurarine (d-TC) and $\alpha$-bungarotoxin ( $\alpha$-Bgt). The blocking of $\alpha$-Bgt suggested that $\alpha 7$ homomeric receptors were involved in the spontaneous action potential induced by IMI [56]. The modulatory effect of neonicotinoids on mammalian nervous systems 
was also studied through the activation of catecholamine release. It was found that in vivo, TMX and its metabolite CLT induced the release of dopamine in the rat striatum. The CLT activated $\alpha 4 \beta 2$ and $\alpha 7$ to induce an in vivo striatal release of dopamine. Intrastriatal infusion of CLT increased extracellular dopamine levels, which was blocked by pretreatment with nAChR antagonists, N-n-decylnicotinium iodide (NDNI), dihydro- $\beta$-erythroidine (DH $\beta E$ ), and methyllycaconitine (MLA) [70]. Moreover, it was found that IMI facilitated tyrosine hydroxylase (TH) transcription via the activation of $\alpha 3 \beta 4$ neuronal nAChRs and $\alpha 7$ receptors. Activation took place at concentrations that are known to produce physiological responses such as catecholamine secretion through the nAChRs in adrenal chromaffin cells. Thus, it was proposed that IMI facilitated the physiological functions of adrenal glands in mammals [71]. In other studies, it was found that exposure to TMX altered behavioral and biochemical processes related to the cholinergic systems in rats. Acetylcholinesterase (AChE) activity was measured in different brain regions such as the hippocampus, striatum, and cortex. It was found that TMX reduced spontaneous motor activity and decreased AChE activity in the hippocampus, cortex, and striatum. The inhibition of AChE activity was long-standing and was accompanied by deficits in behavioral performance [72]. Although the mechanisms leading to the effect of TMX on these brain structures are not well understood, it was hypothesized that TMX activates neuronal nAChRs, leading to an increase in serotonin release, which could explain the anxiogenic effect observed in rats during the plus-maze test [72]. Moreover, all these studies raise the question of a link between neonicotinoids and the blood-brain barrier (BBB) penetration. Indeed, no studies have highlighted a direct adverse effect of neonicotinoids on the BBB, though some have demonstrated an increase of BBB permeability after pyrethrinoid uptake [73,74]. The penetration of neonicotinoids into the mammalian central nervous system has been attributed to their hydrophobicity, which is greater than nicotine [75]. Considering their potential toxic effect through the activation of neuronal nAChRs, studies on the toxicological capacity of neonicotinoids to alter the BBB mechanisms are critical.

\section{Conclusions}

In summary, the enzymatic activity of CYP450 and other enzymes was not sufficient to demonstrate that they can activate resistance in mammals in the same way as in insects. The most evident finding is that neuronal nAChRs are major factors involved in neonicotinoid toxicity in mammalian central nervous systems. We suggest here that neonicotinoid insecticides could differently activate or modulate each neuronal nAChR. The main mechanisms in mammals seem to be a modulatory effect, which will have a consequence on the activation of receptors and the modulation of synaptic activity. Moreover, mammals express different $\mathrm{nAChR}$ subtypes in the peripheral and central nervous systems. The modulatory effect of neonicotinoids found with $\alpha 7$ and $\alpha 4 \beta 2$ suggests that similar mechanisms need to be explored in other mammalian neuronal nAChRs.

Author Contributions: writing—original draft preparation, J.-N.H., A.C., A.L.M., E.T., S.H.T.; writing一review and editing, E.T., S.H.T.; supervision, S.H.T.; funding acquisition, S.H.T. All authors have read and agreed to the published version of the manuscript."

Funding: This research was funded by the Région Centre Val de Loire, "Screenrobot project" and "The manuscript was free of charge".

Acknowledgments: J-N. Houchat and A. Le Mauff received Ph.D. grants from the Région Centre Val de Loire and the French Department of Army (DGA, Direction Générale de l'Armement). A. Cartereau received a grant from the University of Orléans.

Conflicts of Interest: The authors declare no conflict of interest. The funders had no role in the design of the study; in the collection, analyses, or interpretation of data; in the writing of the manuscript, or in the decision to publish the results. The contents of this review are solely the responsibility of the authors. 


\section{References}

1. Changeux, J.-P.; Edelstein, S.J. Allosteric Receptors after 30 Years. Neuron 1998, 21, 959-980. [CrossRef]

2. Changeux, J.-P. The concept of allosteric modulation: An overview. Drug Discov. Today Technol. 2013, 10, e223-e228. [CrossRef] [PubMed]

3. Changeux, J.-P.; Edelstein, S.J. Allosteric Mechanisms of Signal Transduction. Science 2005, 308, $1424-1428$. [CrossRef] [PubMed]

4. Arora, K.; Cheng, J.; Nichols, R.A. Nicotinic Acetylcholine Receptors Sensitize a MAPK-linked Toxicity Pathway on Prolonged Exposure to $\beta$-Amyloid. J. Boil. Chem. 2015, 290, 21409-21420. [CrossRef]

5. Barykin, E.P.; Garifulina, A.I.; Kryukova, E.V.; Spirova, E.N.; Anashkina, A.; Adzhubei, A.A.; Shelukhina, I.V.; Kasheverov, I.E.; Mitkevich, V.A.; Козин, C.A.; et al. Isomerization of Asp7 in Beta-Amyloid Enhances Inhibition of the $\alpha 7$ Nicotinic Receptor and Promotes Neurotoxicity. Cells 2019, 8, 771. [CrossRef]

6. Tanimura, A.; Du, Y.; Kondapalli, J.; Wokosin, D.L.; Surmeier, D.J. Cholinergic Interneurons Amplify Thalamostriatal Excitation of Striatal Indirect Pathway Neurons in Parkinson's Disease Models. Neuron 2019, 101, 444-458. [CrossRef]

7. Leino, S.; Koski, S.; Hanninen, R.; Tapanainen, T.; Rannanpää, S.; Salminen, O. Attenuated dopaminergic neurodegeneration and motor dysfunction in hemiparkinsonian mice lacking the $\alpha 5$ nicotinic acetylcholine receptor subunit. Neuropharmacology 2018, 138, 371-380. [CrossRef]

8. Le Novère, N.; Corringer, P.-J.; Changeux, J.-P. The diversity of subunit composition in nAChRs: Evolutionary origins, physiologic and pharmacologic consequences. J. Neurobiol. 2002, 53, 447-456. [CrossRef]

9. Lukas, R.J.; Changeux, J.P.; Le Novère, N.; Albuquerque, E.X.; Balfour, D.J.; Berg, D.K.; Bertrand, D.; Chiappinelli, V.A.; Clarke, P.B.; Collins, A.C.; et al. International Union of Pharmacology. XX. Current status of the nomenclature for nicotinic acetylcholine receptors and their subunits. Pharmacol. Rev. 1999, 51, 397-401.

10. Lindstrom, J.; Schoepfer, R.; Conroy, W.; Whiting, P.; Das, M.; Saedi, M.; Anand, R. The Nicotinic Acetylcholine Receptor Gene Family: Structure of Nicotinic Receptors from Muscle and Neurons and Neuronal $\alpha$-Bungarotoxin-Binding Proteins. Results Probl. Cell Differ. 1991, 287, 255-278. [CrossRef]

11. Gotti, C.; Zoli, M.; Clementi, F. Brain nicotinic acetylcholine receptors: Native subtypes and their relevance. Trends Pharmacol. Sci. 2006, 27, 482-491. [CrossRef]

12. Anand, R.; Conroy, W.G.; Schoepfer, R.; Whiting, P.; Lindstrom, J. Neuronal nicotinic acetylcholine receptors expressed in Xenopus oocytes have a pentameric quaternary structure. J. Boil. Chem. 1991, 266, 11192-11198.

13. Nelson, M.E.; Kuryatov, A.; Choi, C.H.; Zhou, Y.; Lindstrom, J.; Kohout, T.A.; Lefkowitz, R.J. Alternate Stoichiometries of $\alpha 4 \beta 2$ Nicotinic Acetylcholine Receptors. Mol. Pharmacol. 2003, 63, 332-341. [CrossRef]

14. Zhou, Y.; Nelson, M.E.; Kuryatov, A.; Choi, C.; Cooper, J.; Lindstrom, J. Human alpha4beta2 acetylcholine receptors formed from linked subunits. J. Neurosci. 2003, 23, 9004-9015. [CrossRef]

15. DeDominicis, K.E.; Sahibzada, N.; Olson, T.T.; Xiao, Y.; Wolfe, B.B.; Kellar, K.J.; Yasuda, R.P. The (alpha4)3(beta2)2 Stoichiometry of the Nicotinic Acetylcholine Receptor Predominates in the Rat Motor Cortex. Mol. Pharmacol. 2017, 92, 327-337. [CrossRef]

16. Mazzaferro, S.; Bermudez, I.; Sine, S.M. alpha4beta2 Nicotinic Acetylcholine Receptors: Relationships Between Subunit Stoichiometry and Function at the Single Channel Level. J. Biol. Chem. 2017, 292, 2729-2740. [CrossRef]

17. Maurer, J.; Sandager-Nielsen, K.; Schmidt, H.D. Attenuation of nicotine taking and seeking in rats by the stoichiometry-selective alpha4beta2 nicotinic acetylcholine receptor positive allosteric modulator NS9283. Psychopharmacology 2016, 234, 475-484. [CrossRef]

18. Dani, J.A.; Radcliffe, K.A.; Pidoplichko, V.I. Variations in desensitization of nicotinic acetylcholine receptors from hippocampus and midbrain dopamine areas. Eur. J. Pharmacol. 2000, 393, 31-38. [CrossRef]

19. Séguéla, P.; Wadiche, J.; Dineley-Miller, K.; Dani, J.; Patrick, J. Molecular cloning, functional properties, and distribution of rat brain alpha 7: A nicotinic cation channel highly permeable to calcium. J. Neurosci. 1993, 13, 596-604. [CrossRef]

20. Bertrand, D.; Galzi, J.L.; Devillérs-Thiery, A.; Bertrand, S.; Changeux, J.P. Mutations at two distinct sites within the channel domain M2 alter calcium permeability of neuronal alpha 7 nicotinic receptor. Proc. Natl. Acad. Sci. USA 1993, 90, 6971-6975. [CrossRef] 
21. Maienfisch, P.; Huerlimann, H.; Rindlisbacher, A.; Gsell, L.; Dettwiler, H.; Haettenschwiler, J.; Sieger, E.; Walti, M. The discovery of thiamethoxam: A second-generation neonicotinoid. Pest Manag. Sci. 2001, 57, 165-176. [CrossRef]

22. Wakita, T.; Yasui, N.; Yamada, E.; Kishi, D. Development of a novel insecticide, Dinotefuran. J. Pestic. Sci. 2005, 30, 112-123. [CrossRef]

23. Kagabu, S. Discovery of Imidacloprid and Further Developments from Strategic Molecular Designs. J. Agric. Food Chem. 2011, 59, 2887-2896. [CrossRef]

24. Tan, J.; Galligan, J.J.; Hollingworth, R.M. Agonist actions of neonicotinoids on nicotinic acetylcholine rececptors expressed by cockroach neurons. NeuroToxicology 2007, 28, 829-842. [CrossRef]

25. Thany, S.H. Thiamethoxam, a poor agonist of nicotinic acetylcholine receptors expressed on isolated cell bodies, acts as a full agonist at cockroach cercal afferent/giant interneuron synapses. Neuropharmacology 2011, 60, 587-592. [CrossRef]

26. Nagata, K.; Song, J.H.; Shono, T.; Narahashi, T. Modulation of the neuronal nicotinic acetylcholine receptor-channel by the nitromethylene heterocycle imidacloprid. J. Pharmacol. Exp. Ther. 1998, 285, 731-738.

27. Ihara, M.; Matsuda, K.; Otake, M.; Kuwamura, M.; Shimomura, M.; Komai, K.; Akamatsu, M.; Raymond, V.; Sattelle, D.B. Diverse actions of neonicotinoids on chicken alpha7, alpha4beta2 and Drosophila-chicken SADbeta2 and ALSbeta2 hybrid nicotinic acetylcholine receptors expressed in Xenopus laevis oocytes. Neuropharmacology 2003, 45, 133-144. [CrossRef]

28. Clements, J.; Olson, J.M.; Sanchez-Sedillo, B.; Bradford, B.; Groves, R.L. Changes in emergence phenology, fatty acid composition, and xenobiotic-metabolizing enzyme expression is associated with increased insecticide resistance in the Colorado potato beetle. Arch. Insect Biochem. Physiol. 2019, 103, e21630. [CrossRef]

29. Chen, X.; Tang, C.; Ma, K.; Xia, J.; Song, D.; Gao, X. Overexpression of UDP-glycosyltransferase potentially involved in insecticide resistance in Aphis gossypii Glover collected from Bt cotton fields in China. Pest Manag. Sci. 2019, 76, 1371-1377. [CrossRef]

30. Tang, B.; Dai, W.; Qi, L.; Zhang, Q.; Zhang, C. Identification and Functional Analysis of a Delta Class Glutathione S-Transferase Gene Associated with Insecticide Detoxification in Bradysia odoriphaga. J. Agric. Food Chem. 2019, 67, 9979-9988. [CrossRef]

31. Jin, R.; Mao, K.; Liao, X.; Xu, P.; Li, Z.; Ali, E.; Wan, H.; Li, J.-H. Overexpression of CYP6ER1 associated with clothianidin resistance in Nilaparvata lugens (Stål). Pestic. Biochem. Physiol. 2019, 154, 39-45. [CrossRef]

32. Sun, X.; Gong, Y.; Ali, S.; Hou, M. Mechanisms of resistance to thiamethoxam and dinotefuran compared to imidacloprid in the brown planthopper: Roles of cytochrome P450 monooxygenase and a P450 gene CYP6ER1. Pestic. Biochem. Physiol. 2018, 150, 17-26. [CrossRef]

33. Elzaki, M.E.A.; Miah, M.A.; Wu, M.; Zhang, H.; Pu, J.; Jiang, L.; Han, Z. Imidacloprid is degraded by CYP353D1v2, a cytochrome P450 overexpressed in a resistant strain of Laodelphax striatellus. Pest Manag. Sci. 2017, 73, 1358-1363. [CrossRef]

34. Bao, H.; Gao, H.; Zhang, Y.; Fan, D.; Fang, J.; Liu, Z. The roles of CYP6AY1 and CYP6ER1 in imidacloprid resistance in the brown planthopper: Expression levels and detoxification efficiency. Pestic. Biochem. Physiol. 2016, 129, 70-74. [CrossRef]

35. He, C.; Xie, W.; Yang, X.; Wang, S.-L.; Wu, Q.-J.; Zhang, Y. Identification of glutathione S-transferases in Bemisia tabaci (Hemiptera: Aleyrodidae) and evidence that GSTd7 helps explain the difference in insecticide susceptibility between B. tabaci Middle East-Minor Asia 1 and Mediterranean. Insect Mol. Boil. 2017, 27, 22-35. [CrossRef]

36. Li, Z.; Li, M.; He, J.; Zhao, X.; Chaimanee, V.; Huang, W.-F.; Nie, H.; Zhao, Y.; Su, S. Differential physiological effects of neonicotinoid insecticides on honey bees: A comparison between Apis mellifera and Apis cerana. Pestic. Biochem. Physiol. 2017, 140, 1-8. [CrossRef]

37. Dick, R.A.; Kanne, D.B.; Casida, J.E. Identification of Aldehyde Oxidase as the Neonicotinoid Nitroreductase. Chem. Res. Toxicol. 2005, 18, 317-323. [CrossRef]

38. Dick, R.A.; Kanne, D.B.; Casida, J.E. Substrate Specificity of Rabbit Aldehyde Oxidase for Nitroguanidine and Nitromethylene Neonicotinoid Insecticides. Chem. Res. Toxicol. 2006, 19, 38-43. [CrossRef]

39. Ford, K.A.; Casida, J.E. Unique and Common Metabolites of Thiamethoxam, Clothianidin, and Dinotefuran in Mice. Chem. Res. Toxicol. 2006, 19, 1549-1556. [CrossRef] 
40. Schulz-Jander, D.A.; Casida, J.E. Imidacloprid insecticide metabolism: Human cytochrome P450 isozymes differ in selectivity for imidazolidine oxidation versus nitroimine reduction. Toxicol. Lett. 2002, 132, 65-70. [CrossRef]

41. Schulz-Jander, D.A.; Leimkuehler, W.M.; Casida, J.E. Neonicotinoid Insecticides: Reduction and Cleavage of Imidacloprid Nitroimine Substituent by Liver Microsomal and Cytosolic Enzymes. Chem. Res. Toxicol. 2002, 15, 1158-1165. [CrossRef]

42. Shi, X.; Dick, R.A.; Ford, K.A.; Casida, J.E. Enzymes and Inhibitors in Neonicotinoid Insecticide Metabolism. J. Agric. Food Chem. 2009, 57, 4861-4866. [CrossRef] [PubMed]

43. Swenson, T.L.; Casida, J.E. Aldehyde Oxidase Importance In Vivo in Xenobiotic Metabolism: Imidacloprid Nitroreduction in Mice. Toxicol. Sci. 2013, 133, 22-28. [CrossRef] [PubMed]

44. Swenson, T.L.; Casida, J.E. Neonicotinoid formaldehyde generators: Possible mechanism of mouse-specific hepatotoxicity/hepatocarcinogenicity of thiamethoxam. Toxicol. Lett. 2013, 216, 139-145. [CrossRef]

45. Green, T.; Toghill, A.; Lee, R.; Waechter, F.; Weber, E.; Noakes, J. Thiamethoxam induced mouse liver tumors and their relevance to humans. Part 1: mode of action studies in the mouse. Toxicol. Sci. 2005, 86, 36-47. [CrossRef] [PubMed]

46. Green, T.; Toghill, A.; Lee, R.; Waechter, F.; Weber, E.; Peffer, R.; Noakes, J.; Robinson, M. Thiamethoxam induced mouse liver tumors and their relevance to humans. Part 2: species differences in response. Toxicol. Sci. 2005, 86, 48-55. [CrossRef]

47. Saeed, N.; Tonina, L.; Battisti, A.; Mori, N. Temperature Alters the Response to Insecticides in Drosophila suzukii (Diptera: Drosophilidae). J. Econ. Èntomol. 2018, 111, 1306-1312. [CrossRef]

48. Camp, A.; Buchwalter, D.B. Can't take the heat: Temperature-enhanced toxicity in the mayfly Isonychia bicolor exposed to the neonicotinoid insecticide imidacloprid. Aquat. Toxicol. 2016, 178, 49-57. [CrossRef]

49. Mao, K.; Jin, R.; Li, W.; Ren, Z.; Qin, X.; He, S.; Li, J.; Wan, H. The influence of temperature on the toxicity of insecticides to Nilaparvata lugens (Stål). Pestic. Biochem. Physiol. 2019, 156, 80-86. [CrossRef]

50. Li, P.; Ann, J.; Akk, G. Activation and modulation of human alpha4beta2 nicotinic acetylcholine receptors by the neonicotinoids clothianidin and imidacloprid. J. Neurosci. Res. 2011, 89, 1295-1301. [CrossRef]

51. Cartereau, A.; Martin, C.; Thany, S.H. Neonicotinoid insecticides differently modulate acetycholine-induced currents on mammalian $\alpha 7$ nicotinic acetylcholine receptors. Br. J. Pharmacol. 2017, 175, 1987-1998. [CrossRef] [PubMed]

52. Toshima, K.I.M.; Kanaoka, S.; Tarumoto, K.; Yamada, A.; Sattelle, D.B.; Matsuda, K. Potentiating and blocking actions of neonicotinoids on the response to acetylcholine of the neuronal alpha4beta2 nicotinic acetylcholine receptor. J. Pestic. Sci. 2008, 33, 146-151. [CrossRef]

53. Matsuda, K.; Buckingham, S.D.; Freeman, J.C.; Squire, M.D.; Baylis, H.; Sattelle, D.B. Effects of the $\alpha$ subunit on imidacloprid sensitivity of recombinant nicotinic acetylcholine receptors. Br. J. Pharmacol. 1998, 123, 518-524. [CrossRef]

54. Toshima, K.; Kanaoka, S.; Yamada, A.; Tarumoto, K.; Akamatsu, M.; Sattelle, D.B.; Matsuda, K. Combined roles of loops $\mathrm{C}$ and $\mathrm{D}$ in the interactions of a neonicotinoid insecticide imidacloprid with the alpha4beta2 nicotinic acetylcholine receptor. Neuropharmacology 2009, 56, 264-272. [CrossRef]

55. Hirano, T.; Yanai, S.; Takada, T.; Yoneda, N.; Omotehara, T.; Kubota, N.; Minami, K.; Yamamoto, A.; Mantani, Y.; Yokoyama, T.; et al. NOAEL-dose of a neonicotinoid pesticide, clothianidin, acutely induce anxiety-related behavior with human-audible vocalizations in male mice in a novel environment. Toxicol. Lett. 2018, 282, 57-63. [CrossRef]

56. Bal, R.; Erdogan, S.; Theophilidis, G.; Baydas, G.; Nazıroğlu, M.; Nazıroğlu, M. Assessing the effects of the neonicotinoid insecticide imidacloprid in the cholinergic synapses of the stellate cells of the mouse cochlear nucleus using whole-cell patch-clamp recording. NeuroToxicology 2010, 31, 113-120. [CrossRef]

57. Kagawa, N.; Nagao, T. Neurodevelopmental toxicity in the mouse neocortex following prenatal exposure to acetamiprid. J. Appl. Toxicol. 2018, 38, 1521-1528. [CrossRef]

58. Giordano, G.; Afsharinejad, Z.; Guizzetti, M.; Vitalone, A.; Kavanagh, T.J.; Costa, L.G. Organophosphorus insecticides chlorpyrifos and diazinon and oxidative stress in neuronal cells in a genetic model of glutathione deficiency. Toxicol. Appl. Pharmacol. 2007, 219, 181-189. [CrossRef]

59. Lee, J.E.; Park, J.H.; Shin, I.C.; Koh, H.C. Reactive oxygen species regulated mitochondria-mediated apoptosis in PC12 cells exposed to chlorpyrifos. Toxicol. Appl. Pharmacol. 2012, 263, 148-162. [CrossRef] 
60. Vidau, C.; Polo, R.-A.G.; Niso-Santano, M.; Gómez-Sánchez, R.; Pedro, J.M.B.-S.; Pizarro-Estrella, E.; Blasco, R.; Brunet, J.-L.; Belzunces, L.P.; Fuentes, J.M. Fipronil is a powerful uncoupler of oxidative phosphorylation that triggers apoptosis in human neuronal cell line SHSY5Y. NeuroToxicology 2011, 32, 935-943. [CrossRef]

61. Dhouib, I.E.; Annabi, A.; Doghri, R.; Rejeb, I.; Dallagi, Y.; Bdiri, Y.; Lasram, M.M.; Elgaaied, A.; Marrakchi, R.; Fazaa, S.; et al. Neuroprotective effects of curcumin against acetamiprid-induced neurotoxicity and oxidative stress in the developing male rat cerebellum: Biochemical, histological, and behavioral changes. Environ. Sci. Pollut. Res. 2017, 24, 27515-27524. [CrossRef]

62. Barger, S.; Harmon, A.D. Microglial activation by Alzheimer amyloid precursor protein and modulation by apolipoprotein E. Nature 1997, 388, 878-881. [CrossRef]

63. McDonald, U.R.; Brunden, K.R.; Landreth, G.E. Amyloid Fibrils Activate Tyrosine Kinase-Dependent Signaling and Superoxide Production in Microglia. J. Neurosci. 1997, 17, 2284-2294. [CrossRef]

64. Kamkwalala, A.; Newhouse, P. Beyond Acetylcholinesterase Inhibitors: Novel Cholinergic Treatments for Alzheimer's Disease. Curr. Alzheimer Res. 2016, 13, 1. [CrossRef]

65. Sun, J.L.; Stokoe, S.A.; Roberts, J.P.; Sathler, M.F.; Nip, K.A.; Shou, J.; Ko, K.; Tsunoda, S.; Kim, S. Co-activation of selective nicotinic acetylcholine receptors is required to reverse beta amyloid-induced Ca2+ hyperexcitation. Neurobiol. Aging 2019, 84, 166-177. [CrossRef]

66. Thomsen, M.S.; Arvaniti, M.; Jensen, M.M.; Shulepko, M.A.; Dolgikh, D.A.; Pinborg, L.H.; Hartig, W.; Lyukmanova, E.N.; Mikkelsen, J.D. Lynx1 and Abeta1-42 bind competitively to multiple nicotinic acetylcholine receptor subtypes. Neurobiol. Aging 2016, 46, 13-21. [CrossRef]

67. Hellström-Lindahl, E.; Gorbounova, O.; Seiger, Å.; Mousavi, M.; Nordberg, A. Regional distribution of nicotinic receptors during prenatal development of human brain and spinal cord. Dev. Brain Res. 1998, 108, 147-160. [CrossRef]

68. Miwa, J.; Freedman, R.; Lester, H.A. Neural systems governed by nicotinic acetylcholine receptors: Emerging hypotheses. Neuron 2011, 70, 20-33. [CrossRef]

69. Lozada, A.F.; Wang, X.; Gounko, N.; Massey, K.A.; Duan, J.; Liu, Z.; Berg, D.K. Glutamatergic synapse formation is promoted by $\alpha 7$-containing nicotinic acetylcholine receptors. J. Neurosci. 2012, 32, 7651-7661. [CrossRef]

70. Faro, L.R.F.; Tak-Kim, H.; Alfonso, M.; Duran, R. Clothianidin, a neonicotinoid insecticide, activates alpha4beta2, alpha7 and muscarinic receptors to induce in vivo dopamine release from rat striatum. Toxicology 2019, 426, 152285. [CrossRef]

71. Kawahata, I.; Yamakuni, T. Imidacloprid, a neonicotinoid insecticide, facilitates tyrosine hydroxylase transcription and phenylethanolamine $\mathrm{N}$-methyltransferase mRNA expression to enhance catecholamine synthesis and its nicotine-evoked elevation in PC12D cells. Toxicology 2017, 394, 84-92. [CrossRef] [PubMed]

72. Rodrigues, K.; De Santana, M.B.; Nascimento, J.D.; Picanço-Diniz, D.; Maués, L.; Santos, S.; Ferreira, V.; Alfonso, M.; Duran, R.; Faro, L. Behavioral and biochemical effects of neonicotinoid thiamethoxam on the cholinergic system in rats. Ecotoxicol. Environ. Saf. 2010, 73, 101-107. [CrossRef] [PubMed]

73. Amaraneni, M.; Pang, J.; Mortuza, T.B.; Muralidhara, S.; Cummings, B.S.; White, C.A.; Vorhees, C.V.; Zastre, J.; Bruckner, J.V. Brain uptake of deltamethrin in rats as a function of plasma protein binding and blood-brain barrier maturation. NeuroToxicology 2017, 62, 24-29. [CrossRef]

74. Mortuza, T.B.; Edwards, G.L.; White, C.A.; Patel, V.; Cummings, B.S.; Bruckner, J. Age Dependency of Blood-Brain Barrier Penetration by cis- and trans-Permethrin in the Rat. Drug Metab. Dispos. 2018, 47, $234-237$. [CrossRef]

75. Yamamoto, I.; Tomizawa, M.; Saito, T.; Miyamoto, T.; Walcott, E.C.; Sumikawa, K. Structural factors contributing to insecticidal and selective actions of neonicotinoids. Arch. Insect Biochem. Physiol. 1998, 37, 24-32. [CrossRef]

(C) 2020 by the authors. Licensee MDPI, Basel, Switzerland. This article is an open access article distributed under the terms and conditions of the Creative Commons Attribution (CC BY) license (http://creativecommons.org/licenses/by/4.0/). 